2. Морякіна I. А. Мовна особистість у художній прозі Дж.Голсуорсі: лінгвокогнітивний та прагматичний аспекти (на матеріалі романів форсайтівського циклу): автореф.дис... канд;філол.наук: 10.02.04 / Ірина Анатоліївна Морякіна. Київ: Б.в., 2005. 20 с.

3. Прохоров Ю. Е. Действительность. Текст. Дискурс. М.: Флинта, 2006. $224 \mathrm{c}$.

4. Пушкин А. А. Способ организации дискурса и типология языковых личностей // Язык, дискурс и личность: Межвузовский сб. научных трудов. Тверь: Изд-во ТГУ, 1990. С. 50-60.

5. Сусов И. П. Лингвистическая прагматика. М.: «Восток-Запад», 2006. $323 \mathrm{c}$.

6. Сухих С. А. Личность в коммуникативном процессе / С. А. Сухих. Краснодар: ЮИМ, 2004. 156 с.

7. Biber, D., Conrad, S., and Reppen, R. (1998). Corpus Linguistics. Cambridge University Press, Cambridge

8. Brown, G. and Yule, G. (1983). Discourse analysis. Cambridge University Press, Cambridge.

9. Sherlock transcripts (1-3 seasons). Forever dreaming. Retrieved from https://transcripts.foreverdreaming.org/viewforum.php? $\mathrm{f}=51$ (access date: 25-30.03.21)

10. Translation in context. Sherlock in the original version with English subtitles. URL: https:// www. opensubtitles. org/en/ ssearch/ sublanguageideng/idmovie-59571(access date: 25-30.03.21)

DOI https://doi.org/10.30525/978-9934-26-073-5-1-60

\title{
РОЛЬ КОНТЕКСТУ В МОВЛЕННСВІЙ РЕАЛІЗАЦІЇ ФРАЗЕОЛОГІЗМІВ
}

\author{
Матвіснків О. С. \\ кандидат філологічних наук, \\ доцент кафедри іноземних мов для гуманітарних факультетів \\ Львівського національного університеут імені Івана Франка \\ м. Львів, Украӥна
}

Фразеологія віднаходить широке застосування у художній літературі. У британських художніх текстах мовлення / дискурс антропоморфів значно відрізняється від наукової і побутової форм, і слугує для створення конкретного естетичного та емоційно-художнього впливу на 224 
потенційного читача. Мовлення персонажів, зазвичай, стилізоване i характеризується підбором слів і висловлень, котрі $\epsilon$ засобами художнього зображення антропоморфів літературного твору.

Стилізація передбачає наслідування манери або стилю мовлення, типових для конкретного соціального середовища чи епохи. Як зауважують дослідники художня література конкретного часового відтинку дає естетично перетворену рефлексію і відтворення дискурсу народу відповідно до панівних у ній естетичних, ідейних напрямів й методів творчості (И.В. Арнольд [1], М.П. Брандес [5], С.В. Гладьо [7], Ю.М. Скребнев [10], W. Fleischer [18], L. Hickey [20]).

Мова художнього твору 3 лінгвістичного погляду становить органічну єдність широкого спектра взаємодіючих виражальних засобів, серед яких помітне місце належить фразеологічній одиниці (далі ФО). До слова, В.М. Вакуров [6, с. 26], А.Ш. Тарвердян [12, с. 17], М.О. Фокіна $[14$, с. 28,34$]$, Л.Ф. Щербачук [16, с. 13] досліджуючи стилістику ФО на матеріалі різних мов у різних функційних стилях, усе ж наголошують на провідній ролі фразеологізмів у системі мовних засобів художньої виразовості. Адже можливості формування експресивних емоційнооцінних конотацій у сфері фразеології ширші, ніж у сфері лексики. Тож особливості семантики слова та ФО зумовлюють неоднакове їхне призначення у художньому дискурсі, оскільки у фразеологізмі конотативний елемент значення завжди домінує над денотативним. Фразеологічні одиниці, порівняно зі словами, як зауважує Л.Г. Скрипник, $є$ виразовішими з емоційно-експресивного погляду [11, с. 10]. Здебільшого фразеологізми називають предмети, дії, явища та одночасно й оцінюють їх, виражають ставлення до них, експресивно характеризують.

Естетична роль мовних одиниць (а ФО не є винятком) у художній літературі сьогодення, вважає I.А. Бехта, зумовлена їхньою образністю й емотивністю, а також умінням автора дібрати матеріал і увести його в текст, підпорядкувати авторському задумові [3, с. 212]. Посилення зацікавленості науковців до проблем лінгвістики тексту зумовлює потребу вивчення функцій ФО й у художніх творах. Прикметно, що питанням дієвості фразеологізмів у художніх текстах на матеріалі різних мов присвячено чимало індивідуальних й колективних праць з погляду новітніх розділів мовознавчої науки: когнітивістики $[15,17$ та ін.], прагматики [2, 13, 22, 23 та ін.], дискурсних студій [8, 19, 21 та ін.]. Однак наразі подибуємо мало праць, які висвітлюють фразеологію англійської мови постмодерного періоду.

Вивчаючи функційні особливості фразеологізмів, звертаємося до аналізу структури контексту. Адже ФО поза контекстом становить 
абстрактну схему, яка в кожному випадку наповнюється особливим, властивим лише цьому контексту, змістом [4, с. 72-73].

$Ф О$, виступаючи як компонент художнього тексту, тісно пов'язана 3 контекстом твору. Саме у живому мовленні вона виявляє свій зміст. Аналіз ФО в ізоляції від контексту малоефективний, не забезпечує розкриття глибини її семантики, оскільки фразеологізм вступає у складні смислові стосунки з певним контекстом і залежить від нього. Залежно від змісту контексту, рідше від окремого слова або словосполучення, ФО набуває відповідного звучання.

Зміна структури та лексичного складу (трансформація) сприяє тіснішому зв'язкові ФО зі словами контексту. Внаслідок цього фразеологізм утворює з контекстом єдину змістову цілісність. Якщо слово в контексті може бути нейтральним, то цього аж ніяк не можна категорично сказати про ФО. Наприклад, можемо стверджувати, що ідіоми в художньому творі завжди мають експресивний характер «це наслідок культурної інтерпретації самих фрагментів дійсності 3 метою передати ставлення до них - ціннісне або емоційно значиме» [9, с. 106-109; 13, с. 82].

Отже, студії мовленнєвої реалізації фразеологізмів неможливі без урахування ролі контексту, з яким безпосередньо пов'язана точність сприйняття семантики й використання ФО. Як контекст впливає на фразеологізми, роблячи можливими їхні оказіональні зміни, так і трансформовані ФО впливають зворотно на контекст, тим самим посилюючи його експресивність, емотивність, інформативність. Вивчення ізольованої ФО не дає уявлення про різноманітні зв'язки, у які вона вступає в англійському художньому тексті доби постмодерну.

\section{Література:}

1. Арнольд И.В. Стилистика современного английского языка (Стилистика декодирования). М.: Просвещение, 1990.300 с.

2. Баранов А.Г. Функционально-прагматическая концепция текста / А.Г. Баранов. Ростов-на-Дону: Изд-во Ростов, гос. ун-та, 1993. 182 с.

3. Бехта I.А. Авторське експериментаторство в англомовній прозі XX ст.: монографія. Львів: ПАІС, 2013. 268 с.

4. Білоноженко В.М., Гнатюк I.C. Функціонування та лексикографічна розробка українських фразеологізмів. К.: Наукова думка, 1989. $155 \mathrm{c}$.

5. Брандес М.П. Стилистика текста: теоретический курс: учебник. 3-е изд., перераб. и доп. М.: Прогресс-Традиция; ИНФРА-М, 2004. 416 с. 
6. Вакуров В.Н. Основные проблемы стилистики фразеологических единиц (на материале советского фельетона): автореф. дис. на соискание учен. степени д-ра филол. наук: спец. 10.02.01 / Вакуров В.Н. М.: МГУ, 1983. $48 \mathrm{c}$.

7. Гладьо С.В. Інтерпретація англомовного художнього тексту: лінгвостилістичний аспект / С.В. Гладьо. Вінниця: ВТЕІ КНТЕУ, 2013. $256 \mathrm{c}$.

8. Меликян В.Ю. К вопросу о типологии фразеологического состава языка / В.Ю. Меликян // Язык. Текст. Дискурс: Труды и материалы. Ростов-па-Дону: Изд-во РГПУ, 2005. № 41. С. 195-200.

9. Приходько А.И. Этнолингвистический аспект изучения фразеологии: в кн.: Когнитивные факторы взаимодействия фразеологии со смежными дисциплинами: сб. науч. тр. по итогам III Междунар. науч. конф. (Белгород, 19-21 марта 2013 года) / отв. ред. проф. Н.Ф. Алефиренко. Бел-город: ИД «Белгород» НИУ «БелГУ», 2013. С. 106-109.

10. Скребнев Ю.М. Основы стилистики английского языка / Ю.М. Скребнев. 2-е изд., испр. М.: АСТ; Астрель, 2000. 224 с.

11. Скрипник Л.Г. Фразеологія української мови / Скрипник Л.Г. К.: Наук. думка, 1973. 280 с.

12. Тарвердян А.Ш. Лингво-стилистические особенности вклинивания как приёма обновления фразеологических единиц (на материале английского языка): автореф. дис. на соискание учен. степени канд. филол. наук: спец. 10.02.04 / Тарвердян А.Ш. М., 1985. 22 с.

13. Телия В.Н. Русская фразеология. Семантический, прагматический и лингвокультурологический аспекты. М.: Языки русской культуры, 1996. $288 \mathrm{c}$.

14. Фокина М.А. Фразеологические единицы в повествовательном дискурсе (на материале русской художественной прозы XIX - XX веков): автореф. дис. на соискание учен. степени д-ра филол. наук: спец. 10.02.01 / Фокина М.А. Орел, 2008. 50 с.

15. Шевченко Е.В. Когнитивные аспекты фразеологических единиц, содержащих компонент «цвіт» в современном английском языке: автореф. дис. на соискание учен. степени канд. филол. наук: спец. 10.02.04 / Шевченко Е.В. М., 2010. 20 с.

16. Щербачук Л.Ф. Загальномовна та індивідуально-авторська фразеологія у художніх текстах (на матеріалі художніх творів О. Гончара): автореф. дис. на здобуття наук. ступеня канд. філол. наук: спец. 10.02.01 / Щербачук Л.Ф. Дніпропетровськ, 2000. 20 с. 
17. Boers F., Lindstromberg S. Cognitive Linguistic Approaches to Teaching Vocabulary and Phraseology. Berlin: Walter de Gruyter, 2008.396 p.

18. Fleischer W. Stilistik der deutschen Gegenwartssprache / W. Fleischer (u.a.). 2. Aufl. - Frankfurt am Main (etc.): Peter Lang, 1996. 341 s.

19. Dijk T.A. van. The Study of Discourse // Discourse as Social Interaction. Discourse Studies. № 2. A Multidisciplinary Introduction. L.: SAGE, 1997. P. 1-35.

20. Hickey L. Stylistics, Pragmatics and Pragmastylistics. In: Revue belge de philologie et d'histoire. Tome 71. fasc. 3, 1993. Langues et littératures modernes. Moderne taalen letterkunde. P. 573-586.

21. Johansen J.D. Literary Discourse. A Semiotic-Pragmatic Approach to Literature. Toronto \& L.: University of Toronto Press, 2002. 489 p.

22. Leech G. Explorations in Semantics and Pragmatics. Amsterdam: John Benjamin's Publishing Co., 1980. 230 p.

23. Strässler J. Idioms in English: A Pragmatic Analysis / Jürg Strässler. / Tübinger Beiträge zur Linguistik (B. 183). Gunter Narr Verlag, 1982. 160 p.

DOI https://doi.org/10.30525/978-9934-26-073-5-1-61

\title{
СТРАТЕГІЇ АНГЛОМОВНОЇ КОМУНІКАЦІЇ ТА ÏХ ЛІНГВІСТИЧНИЙ ЗМІСТ
}

\author{
Матковська М. В. \\ дочент кафедри англійської мови \\ Кам'янеиь-Подільського наџіонального університету \\ імені Івана Огієнка \\ м. Кам'янець-Подільський, Хмельницька область, Украӥна
}

Глибинні зв'язки між мовою і культурою є загальновизнаними, але як саме моделі комунікативної поведінки співвідносяться 3 системою культури, являє великий інтерес як для загальної теорії комунікації, так i для опису й аналізу комунікації в межах окремої мовної спільноти.

Наскільки складний і багатогранний сам феномен культури, настільки багатозначне i різноманітне використання цього поняття в різних контекстах різними науками. Услід за Е. Сепіром ми використовуємо термін «культура» як «загальні установки, погляди на життя і специфічні прояви цивілізації, які дозволяють конкретному народу визначити своє місце в світі» [3, с. 469]. Дана концепція найбільш близька нам, оскільки, 228 